\title{
Library Collection Development for Professional Programs: Trends and Best Practices
}

Sara Holder

McGill University, Canada

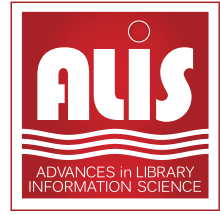


Managing Director:

Senior Editorial Director:

Book Production Manager:

Development Manager:

Assistant Acquisitions Editor:

Typesetter:

Cover Design:
Lindsay Johnston

Heather A. Probst

Sean Woznicki

Joel Gamon

Kayla Wolfe

Jennifer Romanchak

Nick Newcomer

Published in the United States of America by

Information Science Reference (an imprint of IGI Global)

701 E. Chocolate Avenue

Hershey PA 17033

Tel: 717-533-8845

Fax: 717-533-8661

E-mail: cust@igi-global.com

Web site: http://www.igi-global.com

Copyright (C) 2013 by IGI Global. All rights reserved. No part of this publication may be reproduced, stored or distributed in any form or by any means, electronic or mechanical, including photocopying, without written permission from the publisher. Product or company names used in this set are for identification purposes only. Inclusion of the names of the products or companies does not indicate a claim of ownership by IGI Global of the trademark or registered trademark.

\section{Library of Congress Cataloging-in-Publication Data}

Library collection development for professional programs: trends and best practices / Sara Holder, editor. pages $\mathrm{cm}$

Summary: "This book addresses the challenging task of collection development in modern academic libraries and contains practical advice and innovative strategies for current collection development librarians and future librarians seeking guidance in this complex position"--Provided by publisher. Includes bibliographical references and index.

ISBN 978-1-4666-1897-8 (hardcover) -- ISBN 978-1-4666-1898-5 (ebook) (print) -- ISBN 978-1-4666-1899-2 (print \& perpetual access) (print) 1. Academic libraries--Collection development--United States--Case studies. 2. Academic libraries--Collection development--Canada--Case studies. 3. Collection development (Libraries) I. Holder, Sara, 1967Z675.U5L5185 2013

025.2'1877--dc23

\section{8}

British Cataloguing in Publication Data

A Cataloguing in Publication record for this book is available from the British Library.

All work contributed to this book is new, previously-unpublished material. The views expressed in this book are those of the authors, but not necessarily of the publisher. 


\title{
Chapter 7 Collection Development for Theological Education
}

\author{
Geoffrey Little \\ Concordia University, Canada
}

\begin{abstract}
Students in graduate theological programs working toward ordination and a career in ministry in the Christian church require library collections that support their study of scripture, doctrine, ancient languages, and Biblical history and interpretation, as well as the practice of pastoral ministry, leadership, and administration. This chapter will discuss how to build collections at theological libraries measured against standards set by the Association of Theological Schools, the accrediting organization for theological schools in Canada and the United States; the importance of print and online reference works such as language dictionaries, atlases, and encyclopedias in theological library collections; indexes and databases for theological studies; important journals; the different categories of theological monographs; collection development policies; special collections in theological libraries; dealing with gifts and donors; and professional development resources for theological librarians.
\end{abstract}

\section{INTRODUCTION}

The Renaissance scholar Richard Hooker defined "theology" as "the science of things divine" (Hooker, 1907, p. 320), while the Oxford English Dictionary Online entry describes it as "the study or science which treats of God, His nature and attributes, and His relations with man and the universe" (Theology, 2011b). In Europe, the study of theology has its origins in the establishment of the great medieval universities. Theological lectures were taking place at the Universities of Oxford and Paris by the $12^{\text {th }}$ century (University of Oxford, 2009; Université de Paris 1 Panthéon-Sorbonne, 2011), while in North America institutions like Harvard, Yale, Princeton, and Laval in Quebec City were originally founded to train clergymen. Theology as a professional academic program in North America dates from 1807 when the Andover Theological Seminary in Massachusetts was founded and became the first institution to offer a formal course of study leading to a graduate

DOI: 10.4018/978-1-4666-1897-8.ch007

Copyright (C) 2013, IGI Global. Copying or distributing in print or electronic forms without written permission of IGI Global is prohibited. 
degree and a career in ministry and pastoral leadership (Bendroth, 2008, p. 16). Today, libraries at theological schools (which may also be called divinity schools, divinity faculties, seminaries, or theological colleges) or at institutions supporting a professional theological program, collect materials in support of students pursuing master's degrees in preparation for ordination and religious leadership in a branch or denomination of the Christian church, or for careers in religious education, social work, counseling, and chaplaincy. Students may also be working toward doctoral degrees in order to teach at theological schools or religious studies departments, and many theological schools offer professional development and continuing education programs. Areview of the Library of Congress Classification also illustrates the diverse number of subjects that fall under theology including not only God, the Bible and Biblical interpretation, but worship, liturgy, sacraments, religion and mass media, parish work, preaching, missionary activities, as well as the spectrum of major and minor Christian denominations. Readers of this chapter will have a better understanding of how to build and manage library collections that support theological education and theological students. The chapter will also discuss the differences between theology and religious studies, as well as questions of denominational or ideological collection bias.

\section{BACKGROUND}

The word "theology" is derived from the Latin theologia, which itself is derived from two Greek words: theos, the word for God, and logos, noting reason (Theology, 2011a). Plantinga, Thompson, and Lundberg (2010) describe theology, as it is studied and taught in colleges and universities, as "reasoned discourse about God" (p. 6). There are also several branches of theology: biblical theology, the study of the Bible as a way to understand and comprehend God and His revelations through the prophets and the evangelists; historical theology, which applies historical methods to questions about belief, doctrine, and practice; and philosophical theology, which attempts to bring theology into dialogue with other branches of thought and study. Together, these branches may be grouped under the heading of systematic theology, which seeks to present a unified and coherent body of Christian beliefs and practices (Plantinga, et al., p. 17). Pastoral theology is the "study of the care of souls" (Drum, 1912) or the study of active religious ministry.

In North America, those seeking to be ordained in the Roman Catholic, Orthodox, and Protestant churches must hold a degree from an institution accredited by the Association of Theological Schools (ATS), an ecumenical membership organization of graduate theological schools in Canada and the United States. The Association's Commission on Accreditation is responsible for the accreditation process, as well as the ongoing review of accredited programs. Section five of the Commission's "Standards of Accreditation" (2010) deals specifically with library and information resources and acknowledges that the library is "a central resource for theological scholarship and education. It is integral to the purpose of the school through its contribution to teaching, learning, and research, and it functions collaboratively in curriculum development and implementation" (p. 83). The "Standards of Accreditation" also prescribe the requirements for accreditation and ensure that that the quality, form, and shape of theological education are broadly the same at all ATS member schools. Section nine of the ATS's "Handbook of Accreditation" (2006), the tool used to assess theological schools, deals with evaluating library and information resources, including collections. As such, the "Standards of Accreditation" and the "Handbook of Accreditation" are two essential tools that novice and seasoned theological librarians can refer to when building and managing a theological collection. 
Accredited theological schools may be non- or interdenominational, like the Wake Forest University Divinity School or the Union Theological Seminary in New York City, or they may have stated denominational or confessional affiliations like the Jesuit School of Theology at Santa Clara University in California or the Princeton Theological Seminary, a school of the Presbyterian Church (USA). Historically, candidates going on to seek ordination in a specific church attend an educational institution formally or informally affiliated with that church (Weber, 2008). Accordingly, theological library collections will very likely reflect and mirror a school's denominational or confessional affiliation. Theological libraries and collections are found within theological schools that are academic units or faculties within universities or colleges, like those at Vanderbilt, Duke, Oxford, and Cambridge, or they can be departments within large or small stand-alone theological schools like the Vancouver School of Theology, the Graduate Theological Union in Berkeley, California, or the Luther Seminary in St. Paul, Minnesota. Theological collections can also be found in central campus libraries. Collections supporting the University of Chicago Divinity School, for example, are housed in the university's graduate research library, along with other collections in the humanities and social sciences. Some large theological organizations like the American Bible Society or the World Council of Churches also have dedicated libraries, and the Library of Congress and the British Library have important collections of theological materials, including rare and special collections.

The basic graduate professional degree accredited by the ATS leading to ordination and ministry is the Master of Divinity (MDiv) degree. Other basic degrees recognized by the ATS are the Master in Religious Education, Master in Church Music, Master of Specialized Ministry, and Master in Pastoral Studies (Association of Theological Schools, 2007). Theological schools may also offer graduate degrees in theological studies for students not seeking ordination or students who want to teach in theological schools or universities. Advanced degrees in theology, for which the MDiv degree is often required, are the Doctor of Ministry, Doctor of Education, and Doctor of Church Music.

\section{Theology's Relationship to Religious Studies}

What is the difference between theology and the study of religion? Scrimgeour (1985) contends that:

The scholar working in a department of religion is primarily concerned with description and analysis. Methodically, he or she is an agnostic. The theologian, on the other hand, whether working in a university or a seminary, is a self-conscious representative of a particular religious tradition.... the theologian's primary task is to interpret that [particular religious] legacy to society at large, the academy, and the churches. The theologian in the seminary and divinity school environment is actively involved in the education of persons for ministry.... the essence of religion is found in its concern with transcendence, the numinous, the Other, the sacred. (p. 99)

Religious studies can also be viewed as a social science, one that is allied to anthropology, sociology, and psychology and that seeks to understand humanity's shared religious experience, as well as how religions and faiths function and operate as social organizations (Religion, 2009). Parratt (1996) believes that in the academy the study and teaching of theology, as compared to religious studies, "will be limited to those who believe in God in some way...Theology, then, demands some kind of personal commitment over and above the normal kind of commitment one would expect of any scholar in any discipline" (p. 1). 


\section{THE LITERATURE OF THEOLOGY}

The scope of theological literature can be overwhelming given its history and diversity. The oldest work of theological literature is the Old Testament or the Tanakh in Hebrew, the earliest version of which is found in the Dead Sea Scrolls written between circa 150 BC and AD 50 (Dead Sea Scrolls, 2006).

For many decades, collection development in theology, as in other disciplines and professional programs, was focused on the acquisition of printed books and journals. Many libraries also collected materials on microfilm and microfiche and later on computer discs and CD ROMs. Today, almost all scholarly indexes and journals are published online or have some kind of online presence, and the number of electronic books being made available is growing every year, as are the number of printed books. This chapter is intended to give collection development librarians some guidance in identifying important titles, publishers, genres, and resources to use in building collections at theological libraries. It is not exhaustive, and librarians are encouraged to become familiar with the literature through discussions with colleagues and faculty, publishers' catalogs and websites, professional associations, and their own interactions with their library's theological collections. Electronic resources are highlighted along with printed ones, and, as in any other discipline, the librarian must use his or her judgment when evaluating specific resources in terms of projected use in concert with price, demand, quality, and relevance.

Theological literature can be conceived of using several categories defined by material type including: sacred and primary source literature is composed of the Hebrew and Christian Bibles (the Old and New Testaments) as well as the works of early theologians and church fathers like Jerome, Augustine, Thomas Aquinas, John Calvin, Martin Luther, and others, all of whose works are important for understanding the history of Christianity and the development of the branches of the Christian faith; reference works like encyclopedias, dictionaries, atlases, and commentaries; monographs including critical interpretations, textual criticisms, histories, biographies, and analyses of scripture, as well as popular devotional and inspirational texts and how-to manuals; indexes and databases for finding journal articles, essays, and reviews; and journals as vehicles for understanding current scholarship within the various branches of theology and contemporary events within the church.

\section{Sacred and Primary Source Literature}

The Bible, made up of the Old and New Testaments, is the foundation text of the Christian faith and the key to the study, understanding, and application of Christianity and Christian theology. Theological libraries'reference collections should include a number of versions and translations in order to reflect the history, use, interpretation, study, and composition of the Bible and the formation of the Biblical canon by the Catholic, Protestant, and Orthodox branches of the Christian church. A theological library should have, at a minimum, copies of the King James Version (also known as the Authorized Version), the American Standard Version, the New International Version, the DouayRheims Version, the Revised Standard Version, the New English Bible, the Complete Hebrew Bible, the Jerusalem and New Jerusalem Bibles, the Good News Bible, the New American Bible, the Yale Anchor Bible, the New Revised Standard Version, and the Latin Vulgate.

Source literature includes canonical works by the great theologians of the early church, as well as the founders of the branches of the Protestant and Reformed churches. Although these works are not held to be divine or divinely inspired in the same way as the Old and New Testaments, their authors, like Jerome, Augustine, Thomas Aquinas, Martin Luther, John Calvin, and Thomas Cranmer helped 
to shape the theology, identity, and philosophy of the Catholic, Orthodox, and Protestant churches. At the same time, they created distinct intellectual traditions and schools of thought that are central to the way scholars study and teach theology in the twenty-first century.

\section{Reference Works}

Given the technical and highly specialized nature of theological curricula, students require specialized reference tools and resources to help them interpret and understand the Bible and Scripture, theological concepts, ancient languages, and church policy and doctrine.

\section{Bible Dictionaries and Encyclopedias}

Bible dictionaries contain alphabetically arranged articles about persons, events, places, concepts, and institutions mentioned in the Bible. Bible encyclopedias contain longer, more comprehensive entries. The five volume New Interpreters Dictionary of the Bible (Abingdon) is an important recently completed reference work. It or the popular Anchor Bible Dictionary (Doubleday) may function as a library's standard Biblical reference dictionary. The Oxford Companion to the Bible (Oxford), the Catholic Bible Dictionary (Doubleday), Eerdmans Dictionary of the Bible (Eerdmans), and the Cambridge Companion to the Bible (Cambridge) are other important singlevolume print tools. Oxford University Press offers a number of comprehensive digital dictionaries and encyclopedias, through its Oxford Reference Online platform. Here researchers can cross search the electronic versions of the Oxford Dictionary of the Bible (Oxford), the electronic version of the Oxford Companion to the Bible, and the Oxford Guide to People and Places of the Bible (Oxford), as well as resources like the Concise Oxford Dictionary of the Christian Church (Oxford), Concise Companion to the Jewish Religion (Oxford), and Oxford Encyclopedia of the Reformation (Oxford).
Another comprehensive tool for Biblical studies is Oxford Biblical Studies Online. It includes several electronic versions and translations of the Bible, along with images and maps, parallel texts, dictionaries, and critical guides to Biblical themes and topics. Cambridge University Press has made a number of essay collections on specific topics available online through its Cambridge Companions Online series. A subset within the series, "Cambridge Companions to Philosophy, Religion, and Culture" includes over 150 individual online Companions to figures and topics like Anselm, Aquinas, Augustine, Biblical interpretation, Christian doctrine, evangelical and feminist theology, the Gospels, and liberation theology.

\section{Bible Commentaries}

Bible commentaries provide chapter-by-chapter and verse-by-verse explanation and interpretation of the Old and New Testaments arranged in the same order as the books, chapters, and verses of the Bible. Some commentaries consider the entire Bible, while others are concerned only with one book of the Old or New Testaments. Commentaries are essential for Biblical exegesis, the explanation and interpretation of a sacred text. Ascough (2000) defines exegesis as a "systematic process by which a person arrives at a reasonable and coherent sense of the meaning and message of a biblical passage" (para. 1). Exegesis may also seek to explain and analyze intent, apply the meaning to a contemporary situation or event, or use linguistic, historical, and literary methods to interpret the text. As with the Bible, a library should collect a variety of commentaries to reflect the various denominational and confessional perspectives within Christianity. Depending on expected use and other factors, they may be part of a library's circulating collections. Librarians should also bear in mind that the author or authors of a commentary will interpret scripture within the frame of his, her, or their faith or educational background, viewpoint, and theological perspec- 
tive. Commentaries should be used in concert with the appropriate Bible edition or translation so that a researcher seeking to learn about a book or passage within the New International Version Bible, for example, uses a New International Version commentary. Many commentaries are published within series, including the AnchorYale Bible Commentaries series (Yale), Cambridge New Testament Theology Series (Cambridge), Abingdon Old and New TestamentCommentaries, and Fortress Press' Hermeneia series.

\section{Language Dictionaries}

Theological students are expected to gain an understanding of one or more of the ancient Biblical languages of Hebrew, Latin, and Greek through classes that are part the theological curriculum. Some programs may also recommend reading knowledge of a modern European language like German, especially since many theological titles are published in that language. Oxford Reference Online provides electronic access to several electronic bilingual language dictionaries, but librarians may wish to purchase print editions of important titles, especially those with a theological focus. Liddell and Scott's A Greek-English Lexicon (Oxford) is the standard resource for Ancient Greek and the University of Chicago Library has made Woodhouse's English-Greek Dictionary (Oxford), another important work, available online for free (http://www.lib.uchicago.edu/efts/ Woodhouse/). New Testament Greek(also known as Koine Greek) dictionaries and lexicons include Danker's Concise Greek-English Lexicon of the New Testament (Chicago) and Bauer, Arndt, and Gingrich's A Greek-English Lexicon of New Testament (Chicago). Important Latin dictionaries include the Oxford Latin Dictionary (Oxford) and Chambers Murray Latin-English Dictionary (also known as "Smith and Lockwood," J. Murray). Muller's Dictionary of Latin and Greek Theo- logical Terms: Drawn Principally from Protestant Scholastic Theology (Baker House Books) would be useful for schools affiliated with a branch of the Protestant church, while Stelten's Dictionary of Ecclesiastical Latin (Hendrickson, 1995) is useful for Medieval Latin word definitions, along with the use of Latin in liturgy, teaching, and writing in the postclassical period.

A theological library may also consider procuring one or more German language dictionaries, as well as German theological dictionaries like Modern Theological German: A Reader and Dictionary (Baker Books) and Lexikon der theologischen Werke (Kroner).

Theological students require some knowledge of Biblical Hebrew. The Oxford Hebrew Dictionary (Oxford) is a standard resource, as is the Brown, Driver, Briggs Hebrew and English Lexicon (Hendrickson, 1996). Theologically focused resources include Brown's A Hebrew and English Lexicon of the Old Testament (Clarendon Press), the Brill Hebrew and Aramaic Lexicon of the Old Testament (Brill), as well as the Hebrew and Aramaic Dictionary of the Old Testament (de Gruyter).

\section{Biblical Atlases}

Biblical atlases are important for understanding the geography and geographic history of the Bible and the early church. They give important information about how a country, town, city, or region was shaped, populated, administered, and organized, and many include essays, commentaries, charts, and other illustrations. Several atlases are available online through Oxford Biblical Studies Online, such as the electronic version of the Oxford Encyclopedia of Archaeology in the Near East (Oxford). Print sources such as the Oxford Bible Atlas (Oxford), the Macmillan Bible Atlas (Macmillan), and the New Moody Atlas of the Bible (Moody) may also prove useful. 


\section{Concordances}

Concordances identify instances where a word or phrase has been used in the Bible. Many concordances give etymologies along with commentaries and critical interpretation. Print concordances have been largely superseded by electronic versions, including the New American Bible Concise Concordance (Oxford) and Concise Concordance to the New Standard Revised Version (Oxford), both of which are part of Oxford Biblical Studies Online, as well as by any number of free Web-based concordances and computer indexing software like BibleWorks (BibleWorks, LLC). Libraries looking to build a strong core reference collection could consider adding one or more recently published concordances such as Strong's Exhaustive Concordance of the Bible (Hendrickson Publishers), the Analytical Concordance to the New Revised Standard Version of the New Testament (Eerdmans), or the New Standard Revised Version Exhaustive Concordance(Nelson). As with Biblical commentaries, each version and translation of the Bible has its own concordance, such that students using the New Jerusalem Bible should use a New Jerusalem Concordance.

Manuals, Handbooks, and General Reference

This category of reference work includes texts that treat liturgy and worship, liturgical music, and general theological reference, including the Book of Common Prayer in its various international editions, the United Church of Christ's Book of Worship (the Church), the Roman Missal (United States Conference of Catholic Bishops), the Lutheran Book of Worship (Augsberg Fortress), and any other local or national publications such as the Anglican Church ofCanada's Book of Alternative Services (the Church). With regard to church music, librarians may decide to collect these kinds of resources as appropriate and in concert with any campus or institutional music libraries.
General reference works are also important, including dictionaries and guides to theology and theological topics like the print and online versions of Catholic Encyclopedia (Encyclopedia Press), the New Westminster Dictionary of Christian Spirituality (Westminster-John Knox), Dictionary of Historical Theology (Eerdmans), New SCM Dictionary of Liturgy and Worship (SCM), An A to $Z$ of Feminist Theology (Sheffield Academic Press), and the Historical Dictionary of Methodism (Scarecrow Press). Cambridge University Press' Companions series includes many titles that would fall into this general and very useful reference category.

\section{Monographs}

S. L.Peterson(1980), a former librarian of the Yale Divinity School library, writes that "Theology is unusual amongst the humanistic disciplines in that it produces both a highly technical and learned body of literature as well as a much larger body of semi-popular and popular literature which plays an important role in the life of religious people" ( $p$. 153). A theological library's collection can include four broad types of monograph: critical interpretative works that attempt to illuminate a specific aspect of theology, scripture, or doctrine; histories, including biographies, church histories, and the history of Christian thought, philosophy, practice, and worship; practical works on pastoral ministry or parish and congregation administration; and popular devotional, inspirational, or meditative works written for a broad, non-specialist audience and those that discuss one or more contemporary issues or themes.

Many university presses have active theological publishing programs and publish critical works on theological topics, interpretive works by or about modern theologians, and histories and biographies (e.g., Oxford, Cambridge, Baylor, Chicago, Catholic University of America, Notre Dame, and Georgetown). Non-university scholarly publishers that produce theological monographs 
include Ashgate, Peter Lang, Brill, and Brepols. A number of presses produce monographic series like the University of Toronto Press' Erasmus Studies and Lonergan Series, and Wiley's Directions in Modern Theology Series. In addition to collecting texts written by early theologians and doctors of the church, collection development librarians need to ensure that their collections include works by key figures in the history of modern theology like Kant, Hegel, Barth, and Bonhoeffer.

Theological students also require texts to help them learn and understand the practical aspects of their profession and vocation including pastoral ministry, leadership, and management. Clergymen and women are expected to know how to manage funds and staff, deal with advisory boards, committees, and volunteers, administer church buildings, and have the skills to lead, inspire, and counsel the people they have been called to serve. This is a set of skills that students acquire through their courses and in internships and placements; however, they need their libraries to collect practical guidebooks, manuals, and texts in order to help their process of learning and study. Denominational presses publish both critical and investigative theological texts, along with practical guidebooks and handbooks for clergy and those active in pastoral work. Active and important publishers in this field are Abingdon, Fortress, Eerdmans, Westminster John Knox, InterVarsity Press (IVP), the Society for Promoting Christian Knowledge, Brazos, Orbis, SCM, and Albans. The proportion of critical monographs collected in comparison to practical texts or those that focus on aspects of pastoral work will need to be balanced against the library's budget, the curriculum that the library supports, as well as faculty research interests and any school-sponsored projects within the community. Many publishers of practical works are denominationally affiliated, which should be kept in mind when choosing one title over another.

Devotional and inspirational books also have a place in a theological library's collection. These popular works are often concerned with contem- porary issues facing Christians or the church or discuss a particular aspect of Christian faith or practice. They are almost always written with a non-academic audience in mind and can often be biased towards one branch of the Christian church or ideology, but they capture contemporary Christian thought and practice, and reveal contemporary attitudes towards important social questions. Librarians may be loath to add these kinds of mass-marketed books to an academic library's collection, but this category of monograph includes works by important Christian authors like C.S. Lewis, Jean Vanier, Simone Weil, and Billy Graham. It also includes popularly marketed works by scholars and religious leaders like Rowan Williams, Desmond Tutu, Thomas Merton, and Pope Benedict XVI. These titles need to be chosen carefully given other demands on the library's monograph budget, but also to ensure that the ideological or devotional conversation is balanced and appropriate in both shape and tone.

\section{Journals}

The consortial acquisition of large electronic journal packages means that many libraries now have access to hundreds if not thousands of electronic journals across many subjects and disciplines, in which case a discussion about how to build a core theological journal collection is somewhat anachronistic. That said, not every theological librarian has the support of a consortia behind him or her, meaning that building a collection of print and electronic journals requires careful consideration of content, quality, editorial focus, price, and expected use. As well, librarians will want to link to important journals via subject and research guides or identify important titles in classes with students and faculty.

The number of theological and religious studies journals is not small. Some are concerned with questions of theology broadly defined, while others are focused on specific topics like liturgy, scriptural interpretation, or church history. Many journals 
also have specific denominational, ideological, or confessional biases, or geographic interests, while others may be aimed at working clergymen and women rather than scholars or students. Important scholarly journals in theology include: Journal of Theological Studies (Oxford), American Journal of Theology \& Philosophy (University of Illinois Press), Harvard Theological Review (Harvard Divinity School), International Journal for the Study of the Christian Church (Routledge), Journal of the American Academy of Religion (Oxford and the Academy), and Modern Theology (WileyBlackwell). Other publications like Theology Today (Princeton Theological Seminary), and Congregations (Alban Institute) are good tools for pastoral theology and pastoral administration, and First Things (Institute on Religion and Public Life) is an important publication covering events and current issues in theology, theological education, and philosophy. Theological libraries will also want to subscribe to any local publications, such as newspapers or magazines published by their diocese, area, or conference, and they may even wish to collect locally published devotional and service group magazines or newsletters like those produced by the Prayer Book Society or the Catholic Women's League ofCanada, for example.

Libraries with confessional or denominational affiliations will likely want to tailor their journal collections so as to provide comprehensive coverage of current scholarship, intellectual movements, and current events within that church. A library affiliated with the Episcopal or Anglican Church may wish to take the Journal of Anglican Studies (Cambridge), while a school at a Roman Catholic seminary or a Catholic college, will want to subscribe to Pro Ecclesia (Center for Catholic and Evangelical Theology). Faculty teaching and research interests will also have an influence on the shape of the journal collection; however, when selecting journals and making them available, the librarian must always have the program's curriculum in mind, as well as current specializations within the curriculum or historical collecting and research interests.

There are several scholarly journals specifically aimed at promoting the study and teaching of theology including Theological Education (Association of Theological Schools), the Journal of Adult Theological Education (Equinox), and Teaching Theology and Religion (Blackwell and the Wabash Center for Teaching and Learning in Theology and Religion).

\section{Indexes and Databases}

The American Theological Library Association (ATLA) publishes ATLA Religion Database (ATLA RDB) and ATLASerials (ATLAS), the two most important and comprehensive databases for finding journal articles, book reviews, and essays in the fields of theology and religious studies. These two resources are essential for any theological library's collection regardless of size or affiliation. ATLA RDB covers theological publications from 1949 onwards and includes more than 575,000 article citations from over than 1,600 journals, as well as essay and book review citations. Full text is provided for approximately 300,000 electronic articles and book reviews. ATLAS is ATLARDB's full-text companion with over 325,000 records from almost 200 journals.

ATLA also now owns and manages the ATLA Catholic Periodical and Literature Index Online (ACPLI). This resource covers all aspects of the Catholic faith and includes more than 436,000 citations of articles and reviews published in Catholic periodicals, as well as Papal documents, promulgations, and books about the Catholic faith written by Catholics or published by Catholic publishers. Old Testament and New TestamentAbstracts, also published by ATLA, indexes articles about the two books of the Bible, while Ebsco's Religion and Philosophy Collection indexes over 300 full-text journals that cover world religions, religious denominations, and church history. These six databases, ATLA, ATLAS, ACPLI, Old 
and New Testament Abstracts, and Religion and Philosophy Collection, can all be cross searched on the Ebsco platform, which includes Academic Search, Ebsco's powerful online database that indexes over 8,500 scholarly journals in a range of disciplines and subjects. Another useful online resource is Religious and Theological Abstracts, which provides abstracts of articles appearing in a wide range of religious and theological journals in English, Hebrew, Afrikaans, and European languages.

Another important scholarly resource for identifying and accessing journal articles is JSTOR. While JSTOR is technically a journal archive, it has powerful searching capabilities and groups together major journal collections by discipline. Many of these the titles in JSTOR's religion collection consider aspects of non-Christian faiths, but there are a number of significant theological titles in the archive including Church History (American Society of Church History), Novum Testamentum (Brill), and the U.S. Catholic Historian (US Catholic Historical Society). At the time of writing, JSTOR is taking on more and more responsibilities as a publisher of current journals and electronic books, in which case more and more current content in theology may become available through the archive. Finally, given the breadth and power of Google, theological librarians should not exclude Google Scholar from lists of databases and indexes useful for theological students and researchers.

\section{BASIS FOR SELECTION}

\section{Collection Development Policies in Theological Libraries}

A theological library's collection development policy or policies articulate why and what a library collects and to what level. A collection development policy lays out objectives and goals and also relates the work of the library to curriculum and its institution's mission, and it helps create and sustain an environment where selection decisions are made thoughtfully and without bias in support of the library's broader mission to offer resources and services to library users. It should outline any specific denominational or ideological collecting focus. Collection development policies are also useful public relations documents to refer to when selection decisions are challenged or questioned, or when the library is asked to demonstrate its value by administrators, users, or the broader community. The Association of Theological School's "Standards of Accreditation" (2010) require libraries to have a stated collection development policy:

To ensure effective growth of the collection, schools shall have an appropriate collection development policy. Collections in a theological school shall hold materials of importance for theological study and the practice of ministry, and they shall represent the historical breadth and confessional diversity of Christian thought and life (p. 83).

A theological library's collection development policies should be drawn up by the librarian in consultation with his or her dean, department chair, or president in the case of independent theological schools, and it should also involve some consultation with faculty. In composing the policy and in subsequent revisions, librarians should map the collection and collection development to the curriculum at his or her school, along with faculty research and teaching interests, current and historical collections and collection strengths and weaknesses, intuitional affiliation, and local or regional theological collections to which students, faculty, and researchers may also have access. In an effort to promote openness and transparency, a library's collection development policy should be accessible via its website and shared freely amongst library staff, teaching faculty, interested students, and any interested members of the local professional or faith communities. 
Some sample theological collection development policies available online include:

- Andover-Harvard Library, Harvard Divinity School, Cambridge, MA: http:// www.hds.harvard.edu/library/collections/ strengths/collection_development.html

- Catholic University of America Library, Washington, DC: http://libraries.cua.edu/ about/colldev/theology.cfm

- University of Chicago Library, Chicago, IL: http://guides.lib.uchicago.edu/content. php?pid=115216\&sid=1207851

- Graduate Theological Union, Berkeley, CA: http://library.gtu.edu/library/librarydepartments/collection-development/colldevpolicy.pdf/view

- Regis College, University of Toronto, ON: http://www.regiscollege.ca/library/ collections_03

\section{Selection Resources}

Commercial book vendors like Coutts, YBP, Eastern Book Company, and Midwest Library Services can supply theological libraries with new titles on approval plans or they can set up new title alerts based on Library of Congress classification, along with criteria like price, format, language, and readership level. These companies can also procure titles published in Europe and in European languages, but some libraries may be interested in receiving new title alerts from European vendors like Erasmus, Casalini, Aux Amateur de Livres, Harrasowtiz, and Jean Touzot. Librarians doing retrospective collection development may find that they need to use specialized online resources such as AbeBooks or Alibris to obtain older or out of print materials, or they may wish to engage the services of a local book dealer, especially if he or she has an interest or expertise in treating theological or religious titles.

An important tool for identifying theological titles is Religious Studies Review (Wiley-
Blackwell), a quarterly publication founded by the Council of Societies for the Study of Religion. Rice University's department of religious studies has published it since 2009. Annually, it provides 1,000 reviews of books in religious studies, Jewish studies, classics, theology, and related disciplines. Reviews in Religion \& Theology (Hartford Seminary) is another useful resource. Many reviews are written by practicing clergymen and women, as well by scholars and academics. The Review of Biblical Literature (Society of Biblical Literature) publishes reviews of new publications in the fields of theology, religious studies, and Biblical studies by scholars and practitioners in the field and from a variety of theological and ideological perspectives.

As with collection development in other disciplines, publishers' catalogs, announcements, and websites are useful tools for finding out about new publications. Popular review sources such as Choice (Association of College and Research Libraries), the New York Times Book Review (New York Times Co.), the New York Review of Books (New York Review Inc.), and the Times Literary Supplement (Times Newspapers Limited), along with trade publications like Publisher's Weekly (R.R. Bowker) will also cover relevant titles. Almost all scholarly journals in theology and religious studies include a section for book reviews and new title announcements.

Faculty teaching and research interests are important and should obviously be reflected in the collection and in the librarian's selecting practices. Librarians should always welcome purchase requests or suggestions. User input and advice are important in shaping the collection, but they should not be the only method or guiding principle. This can lead to overemphasis in some areas over others or could promote unevenness in the collection if certain titles are lacking or if resources are not present to provide a balanced view of a theme or area of study. At the same time, teaching faculty have an understanding of current scholarly debates, research in the field, 
work being done by scholars at other institutions, and engaging work being undertaken by graduate students, so they should be seen as important allies and resources in collection development.

\section{Other Faith Traditions}

In order to reflect the breadth and scale of humankind's shared religious experiences, a theological library must also have a representative collection of literature on other religions and faith traditions. The Association of Theology School's "Standards of Accreditation" (2010) state that a library's collection "shall include... basic texts from other religious traditions and demonstrate sensitivity to issues of diversity, inclusiveness, and globalization to ensure access to the variety of voices that speak to theological subjects" (p. 83). Given a theological library's mission, user community, and practical issues like budget and shelf space, this kind of collecting must be done carefully and strategically. For example, a library's collection should include a standard translation of the Koran, the foundational text of Islam. Interpretations of the Koran or other aspects of Islamic practice and tradition may not be as important to have in the collection unless there are faculty who teach or do research in that area. The Oxford Handbook of Global Religions (Oxford) the Oxford Handbook of Religious Diversity (Oxford) are examples of two texts that may help the collection development librarian in serving as starting and reference points for incorporating religious pluralism into the collection

\section{Avoiding Bias}

Accusations of bias and even censorship can easily be leveled at theological libraries and librarians if collections are thought to focus on one branch of the Christian church over another or if aspects of a theological movement or philosophy are excluded from the collection. Theological libraries or collections within larger institutions may also be required to justify their collections and the types of materials they purchase, especially if they reside within publically funded secular colleges or universities. As well, many theological librarians are also active in their own faith communities. This gives them a very important and meaningful sense of purpose and reward in relation to their work and often a deep knowledge of the subject. At the same time, theological librarians must also be conscious of their own possible biases when selecting or curating materials or in providing bibliographic access to them. They must approach collection development from a certain personal and emotional distance and employ analytical skills and sound judgment when assessing titles, publishers, and topics, as well as any biases, prejudices, or ideological perspectives that may be present in a title under consideration.

\section{Special Collections}

Given the history of the study and teaching of theology in Europe and North America, many theological libraries have special collections of rare books, as well as manuscripts and archival materials that have accumulated over a number of decades. Some of these were founding collections like the Society of the Propagation of Christian Knowledge collection at the Trinity College, Toronto, or historical bequests like the Sprague Collection of Early American Religious Pamphlets at the Princeton Theological Seminary. Given their unique nature and characteristics, special collections will very likely be tied to the library's denominational or confessional heritage. Depending on the library, its budget, and users, these collections may be growing in response to current research, dedicated endowments, or the library's historical collecting patterns, or they may be collections with little, irregular, or zero growth. Faculty teaching and research interests, along with the strength and importance of existing historical collections, should drive any special collection development and growth. As with the 
circulating or general collection, a library should create policies for the development and management of its special collections. Not only do such policies regulate how the collections may or may not grow, they are useful when dealing with donors and gifts of books, manuscripts, and other kinds of special materials.

\section{Gifts-in-Kind and Donors}

Like most others, theological libraries are the recipients of gifts and donations and they must deal with all the challenges these present. Gifts of books and periodicals may be from faculty clearing out offices, local clergy who are moving or retiring, or from alumni or well-wishers who believe that one or more titles may be useful for the library's collection (and may generate a tax receipt). Gifts may also be received from parishes, churches, or religious groups that, for a variety of selfish or unselfish reasons, want to see a particular title in a library's collection. And, as collection development librarians know, gifts are never free; they require time, expertise, and expense to handle, process, catalog, and maintain.

A relatively short, utilitarian, and easy to apply gift-in-kind policy should be adopted and applied. The library should state what is actively collected and what is not in order to discourage gifts of materials that are not suited for the collection. The policy should ask donors to make lists of materials before delivery so that they can be checked against the library's holdings. It should also clearly state that accepted materials become the property of the library and may be used as the library sees fit so that there are no disagreements about the status of gifts in future years. Gift-inkind policies and forms available online include those from the Phillips Theological Seminary (http://ptstulsa.edu/GivingtotheLibrary) and St. Vladimir's Orthodox Seminary (http://www.svots. edu/sites/default/files/final_compared_gift_acceptance_policy_april_10_word-3.pdf).
At the same time, gifts-in-kind can be very important and can help fill out a collection or gaps in retrospective holdings or special collections, or they can be used as replacement copies if existing ones are battered or in bad condition. Some gifts may include expensive or rate titles that the library would not be able to obtain otherwise.

\section{PROFESSIONAL DEVELOPMENT FOR THEOLOGICAL LIBRARIANS}

In North America, theological librarians can join the American Theological Library Association (ATLA), the organization that produces ATLA RDB, ATLAS, and ACPLI. The Association is ecumenical and promotes ongoing professional development and continuing education for theological and religious studies librarians. It organizes an annual conference and, with the University of Illinois at Urbana-Champaign, it sponsors a course on theological librarianship. In addition to publishing its indexes and databases along with other works on theological librarianship, since 2008 it has published the online open access peer-reviewed journal Theological Librarianship. The Association also has an active listserv, ATLANTIS-L, which is useful for querying assembled knowledge, arranging for print journal back file exchanges, and seeking general theological librarianship advice. Collection development librarians may wish to follow the work of ATLA's Collection Evaluation and Development Interest Group (CEAD). CEAD has a dedicated listserv, ATLACEAD-L, for collection development and management related queries and posts. ATLA also has faith-based interest groups/chapters, but Roman Catholic librarians or librarians at schools affiliated with the Catholic Church can join the Catholic Library Association, which publishes the Catholic Library World, and evangelical librarians will find a home in the Association of Christian Librarians. 
The Journal of Religious \& Theological Information (Taylor and Francis) publishes peer-reviewed articles on aspects of theological librarianship and information management and allied fields like religious studies. In the United Kingdom, theological librarians can become members of the Association of British Theological and Philosophical Libraries (ABTAPL), and the Australian and New Zealand Theological Library Association(ANZTLA) encourages and supports theological and religious studies librarians in those two countries.

The Wabash Center for Teaching and Learning in Theology and Religion is another important resource for theological educators and librarians. It publishes the aforementioned Teaching Theology and Religion, but also the Internet Guide to Religion, which links to useful websites, resources, publications, and tools, as well as to syllabi from theological and religious studies courses.

\section{CONCLUSION}

Collection development in support of theological education and theological students presents distinct challenges as well as distinct rewards. Theological librarians are expected to collect and make available scholarly monographs and practical handbooks, specialized article databases, journals, reference works, and other specialized materials in order to support students and faculty. At the same time, theological libraries are supporting the formation and training of the next generation of Christian clergymen and women, along with lay leaders, educators, and scholars. In this sense, theological librarianship is a fundamental form of stewardship and an investment in the direction and future of the Christian church. Theology as a professional degree program seeks to find a balance between scholarship through the study of doctrine, ancient languages, and scripture, and active learning gained by working in parishes or congregations and other hands-on experiences. The theological library and its collections, then, must endeavor to provide the tools necessary for a comprehensive, thoughtful, rigorous, and stimulating theological education. Given the history of the study of theology in both Europe and North America, theological librarianship is one of the oldest kinds of librarianship and it is part of a rich tradition of scholarship, teaching, and research.

As it is in other fields, more and more theological information is being made available online, in which case librarians are faced with trying to predict what tools and resources purchased or subscribed to now will be useful in the next one, three, or five years. The scholarly community has embraced online journals. Will it be much longer before electronic books are available in a format that facilitates widespread adoption? Will theological publishers adopt the e-book, or will theology remain a print-focused discipline? Electronic reference sources, while expensive, provide a number of excellent features, but can collection development librarians justify their cost, especially when they already have the print sources on their shelves? These questions will very likely be succeeded by others in the coming years, but theological librarians should always bear in mind that nothing is fixed within the literature of theology save a desire to know and comprehend God. As students and scholars continue to explore questions around God, doctrine, Christian tradition, practice, and worship, the scriptures remind librarians "Of making many books there is no end.” (Ecclesiastes 12:12, King James Version).

\section{REFERENCES}

Ascough, R. S. (2000). Guide to Biblical exegesis. Retrieved from http://post.queensu.ca/ rsa/ Exegesis_Guide.htm. 
Association of Theological Schools. (2006). Handbook of accreditation. Retrieved from http:// www.ats.edu/Accrediting/Documents/Handbook/ Section9.pdf.

Association of Theological Schools. (2007). Approved degrees offered by members schools. Retrieved from http://www.ats.edu/MemberSchools/ Pages/Degrees.aspx.

Association of Theological Schools. (2010) Standards of accreditation. Retrieved from http:// www.ats.edu/Accrediting/Documents/GeneralInstitutionalStandards.pdf.

Bendroth, M. L. (2008). A school of the church: Andover Newton across two centuries. Grand Rapids, MI: Wm. B. Eerdmans.

Drum, W. (1912). Pastoral theology. In The Catholic Encyclopedia. Retrieved from http:// www.newadvent.org/cathen/14611a.htm.

Hooker, R. (1907). Hooker's ecclesiasticalpolity, books I-IV. London, UK: J. M. Dent.

Livingstone, E.A.(Ed.). (2006). Dead Sea scrolls. In E. A. Livingstone (Ed.), The Concise Oxford Dictionary of the Christian Church. Retrieved from http:/www.oxfordreference.com/views/ ENTRY.html?subview=Main\&entry=t95.e1595.

Parratt, J. (1996). A guide to doing theology. London, UK: SPCK.

Peterson, S. L. (1980). Collection development in theological libraries: Anew model-A new hope. In De Klerk, P., \& Hilgert, E. (Eds.), Essays on Theological Librarianship presented to Calvin Henry Schmidt (pp. 143-162). Philadelphia, PA: American Theological Library Association.

Plantinga, R. J., Thompson, T. R., \& Lundberg, M. D. (2010). An introduction to Christian theology. Cambridge, UK: Cambridge University Press.
Scrimgeour, A. D. (1985). Philosophy and religion. In McClung, P. A. (Ed.), Selection of Library Materials in the Humanities, Social Sciences, and Sciences (pp. 98-121). Chicago, IL: American Library Association.

Religion (2009). In J. Scott \& G. Marshall (Eds.), A Dictionary of Sociology. Retrieved from http:// www.oxfordreference.com/views/ENTRY. $\mathrm{html}$ ?subview=Main\&entry=t88.e1916.

Tapper, J. (2006). Dewey does a number on Wicca. Library Journal, 131(8), 16.

Theology. (2011a). Encyclopcedia Britannica. Retrieved from http://0-www.britannica.com. mercury.concordia.ca/EBchecked/topic/590855/ theology.

Theology. (2011b). Oxford English dictionary. Retrieved from http://www.oed.com/view/Entry/200388.

Université de Paris 1 Panthéon-Sorbonne. (2011). La première moitié du XIIIe siècle. Retrieved from http://www.univ-paris 1.fr/universite/ presentation/historique/la-premiere-moitie-duxiiie-siecle/.

University of Oxford. (2009). About the faculty. Retrieved from http://www.theology.ox.ac.uk/ about-the-faculty.html.

Weber, T. P. (2008). The seminaries and the churches: Looking for new relationships. Theological Education, 4, 65-91.

\section{ADDITIONAL READING}

Engler, S. (2007). Theory of religion: Resources for libraries. Behavioral \& Social Sciences Librarian, 26(2), 29-45. doi:10.1300/J103v26n02_03

Gentz, W. H. (1989). The Bible in church and synagogue libraries. Portland, OR: Church \& Synagogue Library Association. 
McMahon, M. L., \& Stewart, D. R.(Eds.). (2006). A broadening conversation: Classic readings in theological librarianship. Lanham, MD: Scarecrow Press.

Newhall, J. E. (1970). A theological library manual. London, UK: Theological Education Fund.

Petersen, R. L., \& Rourke, N. M. (Eds.). (2002). Theological literacy for the twenty-first century. Grand Rapids, MI: Wm. B. Eerdmans.

Prichett, J. (1987). Providing reference service in church and synagogue libraries. Portland, OR: Church \& Synagogue Library Association.

Smalley, M. L. (1996). Archives and manuscript collections in theological libraries. In Graham, P. M., Hotchkiss, V. R., \& Rowe, K. E. (Eds.), The American Theological Library Association: Essays in Celebration of the First Fifty Years (pp. 122-130). Evanston, IL: American Theological Library Association.

Smith, G. A. (Ed.). (2002). Christian librarianship: Essays on the integration of faith and profession. Jefferson, NC: McFarland.

\section{KEY TERMS AND DEFINITIONS}

Bible Commentaries: Works providing chapter-by-chapter and verse-by-verse explanation and interpretation of the Old and New Testaments arranged in the same order as the books, chapters, and verses of the Bible.

Bible Concordances: Works that identify instances where a word or phrase has been used in the Bible and may give etymologies along with commentaries and critical interpretation.

Denominational Affiliation: The religious group to which an institution or person belongs or follows.

Master of Divinity (MDiv) Degree: Basic graduate professional degree accredited by the Association of Theological Schools leading to ordination and ministry.

Religious Studies: The study of religions in human culture as well as the way religious concepts are expressed in texts, rituals, and belief systems. 